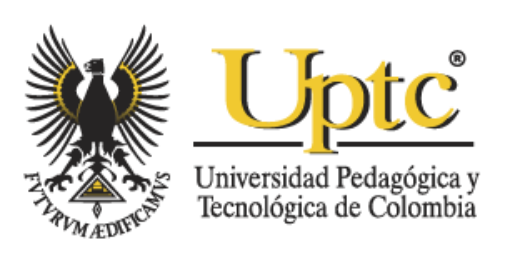

\title{
Sero-prevalence of brucellosis
}

\section{(Brucella abortus) in bovines from}

\section{Caquetá state, Colombia}

Pablo Andrés Motta-Delgado, Ricardo Alberto MartínezTovar, Marliyanini Londoño-Giraldo, Erika Paola RojasVargas \& Wilmer Herrera-Valencia

Citación: Motta-Delgado, P. A., Martínez-Tovar, R. A., Londoño-Giraldo, M., Rojas-Vargas, E. P., \& HerreraValencia, W. (2020). Sero-prevalence of brucellosis (Brucella abortus) in bovines from Caquetá state, Colombia. Ciencia y Agricultura, 17(1), 19-30.

https://doi.org/10.19053/01228420.v17.n1.2020.9917

Recibido: Agosto 6, 2019; Aceptado: Octubre 18, 2019; Publicado: Enero 15, 2020

Derechos de reproducción: Este es un artículo en acceso abierto distribuido bajo la licencia Creative Commons Attribution License (CC BY). 


\title{
Sero-prevalence of brucellosis (Brucella abortus) in bovines from Caquetá state, Colombia
}

\author{
Pablo Andrés Motta-Delgado ${ }^{1}$ \\ Ricardo Alberto Martínez-Tovar² \\ Marliyanini Londoño-Giraldo ${ }^{3}$ \\ Erika Paola Rojas-Vargas ${ }^{4}$ \\ Wilmer Herrera-Valencia ${ }^{5}$
}

\begin{abstract}
Brucellosis is a disease with implications in the public health due both to its zoonotic character as its easy transmission trough of dairy products contaminated with the microorganism Brucella sp. The aim of this article was determinate the prevalence of bovine brucellosis in nine municipalities that carrying the $75 \%$ of bovine population in the Caquetá state, Colombia. Blood samples were collected in 100 herds dedicates to dual-purpose cattle, obtained blood serum from 1000 animals, of which 882 corresponding to cows. Rose Bengal Plate Test was performed and the confirmations of positive cases were made by competitive Elisa. The sero-prevalence of bovine brucellosis in Caquetá state was of $3.23 \%(95 \%, \mathrm{Cl}$ : $0-6.53 \%$ ), in males $2.6 \%$ and females $3.29 \%$ respectively. At the municipal level, the sero-prevalence varied of 0 to $6.06 \%$. The prevalence of brucellosis at herd level was of $22 \%(95 \%, \mathrm{Cl}: 12.24-31.76 \%)$. In conclusion, the sero-prevalence is low in bovines but moderate at the level of herds, therefore, it is necessary to increase the performance of the official control entities at the level of herds to reduce the high prevalence of the disease for guaranteed the safety of milk and thus the health of consumers.
\end{abstract}

Keywords: agroecosystem; Amazonia; dual-purpose cattle; epidemiology; public health; zoonosis.

\footnotetext{
${ }^{1}$ M. Sc. Misión Verde Amazonia (Florencia-Caquetá, Colombia). pmotta@misionverdeamazonia.org. ORCID: 0000-0001-8820-5542.

${ }^{2}$ M. Sc. Misión Verde Amazonia (Florencia-Caquetá, Colombia). ORCID: 0000-0001-5615-6715.

${ }^{3}$ Misión Verde Amazonia (Florencia-Caquetá, Colombia). ORCID: 0000-0003-4454-7780.

${ }^{4}$ Misión Verde Amazonia (Florencia-Caquetá, Colombia). ORCID: 0000-0003-4654-9368.

5 M. Sc. Misión Verde Amazonia (Florencia-Caquetá, Colombia). gerencia@misionverdeamazonia.org. ORCID: 0000-0001-9263-8711.
} 
Desarrollo del girasol (Helianthus annuus L.) con aplicación de codornaza bajo distintas láminas de riego

\section{Seroprevalencia de brucelosis (Brucella abortus) en bovinos del departamento del Caquetá, Colombia}

\section{Resumen}

La brucelosis es una enfermedad con implicaciones en la salud pública tanto por su carácter zoonótico como su fácil transmisión a través de lácteos contaminados con el microorganismo Brucella sp. El objetivo del presente artículo fue determinar la prevalencia de brucelosis bovina en nueve municipios que contienen el $75 \%$ de la población bovina en el departamento del Caquetá, Colombia. Fueron colectadas muestras de sangre en 100 predios ganaderos dedicados al sistema de doble propósito, obteniendo suero sanguíneo de 1000 animales, de los cuáles 882 correspondieron a vacas. Se realizó la prueba Rosa de Bengala y confirmación de los casos positivos mediante Elisa Competitiva. Se obtuvo una seroprevalencia general de $3,23 \%(95 \%$, IC: $0-6,73 \%)$, en el departamento del Caquetá, $2,6 \%$ en machos y de $3,29 \%$ en hembras respectivamente. A nivel municipal la seroprevalencia varió desde el $0 \%$ hasta el $6,06 \%$. La prevalencia de brucelosis a nivel de predios fue del 22\% (95\%, IC: 12,24-31,76\%). En conclusión, existe una seroprevalancia baja en animales, pero moderada en hatos, por tanto, se hace necesario una mayor actuación de las entidades de control oficial a nivel de las fincas para reducir la alta prevalencia de la enfermedad para garantizar la inocuidad de la leche y por tanto de la sanidad de los consumidores.

Palabras clave: agroecosistema; Amazonia; doble propósito; epidemiología; salud pública; zoonosis.

Para citar este artículo:

Motta-Delgado, P. A., Martínez-Tovar, R. A., Londoño-Giraldo, M., Rojas-Vargas, E. P., \& Herrera-Valencia, W. (2020). Sero-prevalence of brucellosis (Brucella abortus) in bovines from Caquetá state, Colombia. Ciencia y Agricultura, 17(1), 19-30. https://doi.org/10.19053/01228420.v17.n1.2020.9917

Esta obra está bajo licencia internacional Creative Commons Reconocimiento 4.0

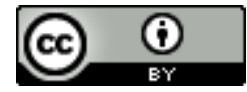




\section{INTRODUCTION}

Brucellosis is a highly contagious bacterial infection of livestock and continues to be of great health concern and economic importance in worldwide (Maadi, Moharamnejad, \& Haghi, 2011); (Pathak et al., 2016). This disease is caused by aerobic gram-negative bacteria of the genus Brucella, which affect domestic animals, wild animals and human, being an important public health problem in many parts of world (Aguirre et al., 2008; Reyes, Sánchez, Lotero, Restrepo, \& Palacio, 2010; Akbarmehr \& Ghiyamirad, 2011), and the brucellosis is considering a re-emerging zoonosis (Seleem, Boyle, \& Sriranganathan, 2009). According to Aguirre et al. (2008), Matope et al. (2011) and Astaiza, 2012, brucellosis in Colombia has caused high economic losses in the livestock production, estimates are 7 to 12 million of dollars each year according to evaluations between 1993 and 1999.

In the bovine cattle the brucellosis causes infertility, abortion, early calf death, low milk yield and reproductive failure when the infection with the $B$. abortus strain occurs (Alton \& Forsyth, 2003; Castro, González, \& Prat, 2005; Carvalho-Neta, Mol, Xavier, Paixão, Lage, \& Santos, 2010). Brucellosis is spread through contact for the oral, nasal and conjunctival, with aborted fetuses, vaginal fluids, placentae, placental fluids, and milk, as well as through congenital and venereal means (Castro, González, \& Prat, 2005; Ayinmode, Akinseye, Schares, \& Cadmus, 2017).

The bovine population in the Caqueta state amounts in the $1,686,852$ animals, where 374,317 are females older than 36 months, this state is the fifth dairy basin more important of Colombia (Beltrán-Barreiro \& Torrijos, 2013), with a milk production higher to $1,215,833 \mathrm{~kg}$ per day, the which obtains $90 \%$ in nine municipalities. Until the year 2013, 32 municipalities were certificated free of bovine brucellosis, however, none from the Caquetá state (FEDEGAN, 2013). The objective of this research was determinate the prevalence of bovine brucellosis in the nine municipalities that produce $90 \%$ of milk in the Caquetá state.

\section{Materials AND MethodS}

\section{A. Area of Study}

The research was made in nine municipalities from Caquetá State, located to the south of Colombia and the northeast of the Colombian Amazonia, between the $00^{\circ} 42^{\prime} 17^{\prime \prime}$ of latitude south and $02^{\circ} 04^{\prime} 13$ " of latitude north, and the $74^{\circ} 18^{\prime} 39^{\prime \prime}$ and $79^{\circ} 19^{\prime} 35^{\prime \prime}$ of longitude west of Greenwich. Borders to the North with both Meta and Guaviare states, to the east with both Vaupes and Amazonas states, to the south with the Putumayo and the west with both Cauca and Huila states; the Caquetá state has an extension of $88,965 \mathrm{~km}^{2}$ and is politically divided into 16 municipalities (Caquetá Gobernación de, 2012). The municipalities involved in the study were Albania, San José del Fragua, La Montañita, Milán, El Paujil, El Doncello, Cartagena del Chairá, Puerto Rico and San Vicente del Caguán. 
Desarrollo del girasol (Helianthus annuus L.) con aplicación de codornaza bajo distintas láminas de riego

In the Caquetá state has three thermal floors (cold, temperate and warm) (Corpoica, 1998; García, Cipagauta, Gómez, \& Gutierrez, 2002). In the warm climate that covers the greatest area to state, the average precipitation is of 3800 $\mathrm{mm} /$ year, without dry station well defined, (nevertheless, the lower precipitation is registered between December to January and the greater precipitation between March to November), the rainfall erosivity index $\left(R\right.$ or $\left.\mathrm{El}_{30}\right)$ multiannual is the 2750 $\mathrm{tm} / \mathrm{cm} / \mathrm{ha} / \mathrm{h}$, value three times greater than other regions of country, the relative humidity is greater than $80 \%$, but can fluctuate between 64 to $93 \%$, with temperatures range between 18 to $36{ }^{\circ} \mathrm{C}$ with an average annual of $25{ }^{\circ} \mathrm{C}$ characteristic of a regime isohyperthermic. The evapotranspiration potential is $1,435 \mathrm{~L} / \mathrm{m}^{2} /$ year, the average of solar radiation is of 1,800 hours/year and the intensity of $268 \mathrm{cal} / \mathrm{m}^{2} /$ day. The climatic characteristics in the study area are of tropical rainforest (Holdridge, 1978).

\section{B. Sample Size}

Using the information of the agricultural assessment 2016 of the secretary of Agriculture of Caquetá state, the total of bovines females older to 36 months were of 374317 (Caquetá, 2016). Was calculated the sample size from a known population, using the equation (1).

$$
n=\frac{\left(N \times Z_{a}^{2} \times p \times q\right)}{\left[d^{2} \times(N-1)+Z_{a}^{2} \times p \times q\right]}
$$

Where $n=$ sample size, $N=$ population size $(374,317), Z=$ confidence level $(95 \%)$, $p=$ probability of success $(0.5), q=$ probability of failure $(0.5)$, and $d=$ precision (maximum allowable in terms of ratio error) (3.5\%), thus was estimated a minimum sample size of 782 females older to 36 months.

For determinate to sample size for the dual purpose herds was used the previous equation with the following assumptions: $N=$ population size $(11,128), Z=$ confidence level $(95 \%), p=$ probability of success $(0.5), q=$ probability of failure $(0.5)$, and $d=$ precision (maximum allowable in terms of ratio error) $(10 \%)$, thus was estimated a minimum sample size of 95 herds of dual purpose.

\section{Selection of Herds}

The herds were selected from the database of project Implementación y validación de modelos alternativos de producción ganadera en el departamento del Caquetá, taking into account the 500 herds of dual-purpose cattle distributed in nine municipalities of state, and the criteria proposed by Yamamoto et al. (2007), were used, but modified for this research: a) the farm size (50-180 hectares), b) farms with more than 10 cows in milking (older to 36 months), c) availability to cooperate in the project, and d) accessibility and roads in good conditions.

\section{Ethics Aspects}

The samples were taken by Veterinarians and endorsed by the inspectors of the entity of inspection authorized by the Colombian Agricultural Institute (ICA by the acronyms in Spanish) in the Florencia branch, following the ethics, technical, 
scientific and administrative regulations for the research with animals, according to the law 84 of 1989. Throughout the research, the confidentiality of farms positives to brucellosis was maintained. The project was approved by the resolution 005 of 2013 by the Science, Technology, and Innovation Fund (FCTel) of the National Planning Department (DNP) of Colombia with the advice of Colciencias as technical secretariat.

\section{E. Diagnosis}

Between the months of January to March of 2016 blood serum sampling were carried out in 100 herds dedicated to the dual purpose cattle system, in each were sampled ten livestock ( 9 cows and 1 Bull) older to 36 months for a total to 1000 bovines.

To obtain blood samples, venipuncture was performed in the coccygeal vein preliminary cleaning and disinfection of the area with ethyl alcohol at $70 \%$, the blood samples were deposited in sterile tubes without anticoagulant (red top) to ensure that the serum obtained, all samples were properly labeled the animal information: identification, sex, age, identification to herd and date of sampling, Subsequently, the blood samples were stored in thermos conveyors maintaining refrigeration at $4-8^{\circ} \mathrm{C}$. All samples were sent to the laboratory of veterinary Diagnostics of the Colombian Agricultural Institute (ICA) in the Florencia city.

In the laboratory of Veterinary Clinical Diagnostics was conducted the tests established by the ICA for the diagnosis of brucellosis in Colombia (Resolution 0840, 2011), blood serum was obtained and was carried out with Pink Bengal agglutination technique as a test sieve, with a particulate Antigen consisting of whole strains 1119-3-cell or C99 of $B$. abortus that interacts with serum producing a network of agglutination dependent on optimal proportions of the reactants. Antigen dampens $\mathrm{pH}$ low, by the addition of pink Bengal dye, buffered usually 3.65 \pm 0.05 , since the non-specific agglutination of smooth Brussels boils down to $\mathrm{pH}$ low, favoring the activity of type IgG1 specific antibodies, testing has shown high although confirmatory test because of its specificity it requires relatively low sensitivity, therefore the positive Rose Bengal Plate Test results in blood serum must be confirmed by the competitive Elisa test (Dussan-Embus, CastañedaRepizo, \& Durán-Bautista, 2012). All serums with positive results to the previous test were subjected to confirmation by the technique of competitive Elisa Test.

Data were tabulated in an Excel spreadsheet and subsequently analyzed by descriptive statistics using the statistical software InfoStat (Di Rienzo, Casanoves, Balzarini, González, Tablada, \& Robledo, 2017), contingency tables for analysis of categorized data were used, and also, ANOVA was performed with LSD Fisher test at 0.05 of significance level. 
Desarrollo del girasol (Helianthus annuus L.) con aplicación de codornaza bajo distintas láminas de riego

\section{Results AND Discussion}

In total were sampled 1000 bovines distributed in 100 herds of dual-purpose cattle, of which 882 blood serum corresponding to females, 77 to Bulls and 41 to hemolyzed blood serum.

Sero-prevalence of bovine brucellosis in the Caquetá state was of $3.23 \%(95 \%, \mathrm{Cl}$ : $0-6.53 \%$ ), with the highest prevalence in females than in males (Table 1).

Table 1. Sero-prevalence of bovine brucellosis in the Caquetá State

\begin{tabular}{lcccccc}
\hline \multirow{2}{*}{ Result } & \multicolumn{2}{c}{ Females } & \multicolumn{2}{c}{ Males } & \multicolumn{2}{c}{ Total } \\
& Cases & $\%$ & Cases & $\%$ & Cases & $\%$ \\
\hline Negative & 853 & $96.71^{\mathrm{a}}$ & 75 & $97.40^{\mathrm{a}}$ & 928 & $96.77^{\mathrm{a}}$ \\
Positive & 29 & $3.29^{\mathrm{b}}$ & 2 & $2.60^{\mathrm{b}}$ & 31 & $3.23^{\mathrm{b}}$ \\
Total & $\mathbf{8 8 2}$ & $\mathbf{1 0 0 . 0 0}$ & $\mathbf{7 7}$ & $\mathbf{1 0 0 . 0 0}$ & $\mathbf{9 5 9}$ & $\mathbf{1 0 0 . 0 0}$ \\
\hline
\end{tabular}

Value with the same letter does not have a statistically significant $(p<0.05)$.

At the municipal level were found percentages higher than the sero-prevalence in the state, as in the case of the San Vicente del Caguán, San José del Fragua, Milán, and Cartagena del Chairá municipalities, for La Montañita and El Doncello the seroprevalence was of $0 \%$, however, statistical difference was not found (Figure 1).

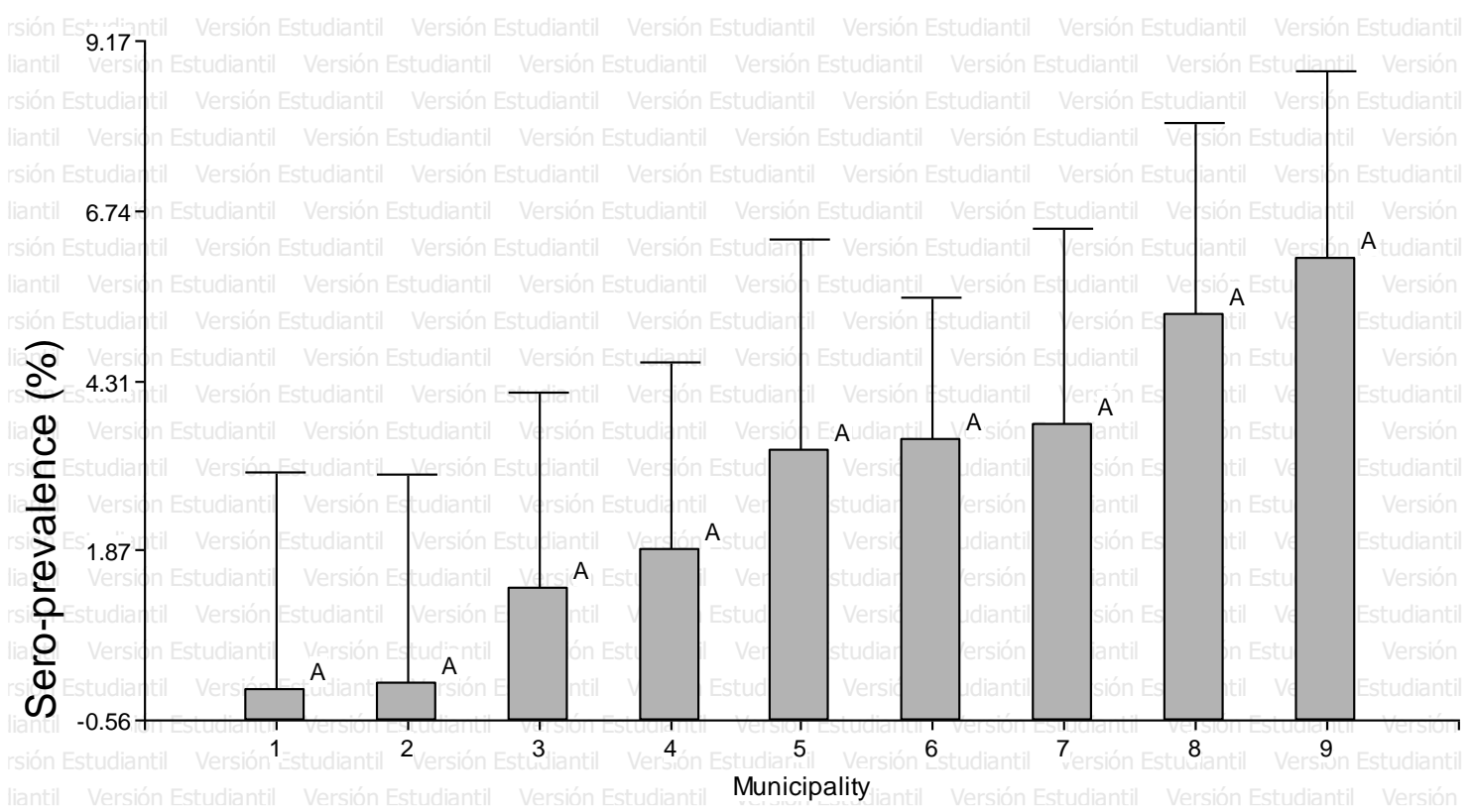

Fig. 1. Seroprevalence of bovine brucellosis in nine municipalities of the Caquetá state. 1: La Montañita, 2: El Doncello, 3: El Paujil, 4: San José del Fragua, 5: Milán, 6: San Vicente del Caguán, 7: Cartagena del Chairá, 8: Albania and 9: Puerto Rico.

Of the 77 bulls analyzed only two (2) were positives for brucellosis, being a seroprevalence of $2.6 \%$ respect to all male's samples. In the females, the seroprevalence of bovine brucellosis was of the $3.29 \%$ obtaining 10 positives livestock by competitive Elisa test. 
The positives cases for bovine brucellosis were meet in 22 herds of seven municipalities, thus the prevalence of disease at farm level was of $22 \%(95 \%, \mathrm{Cl}$ : 12.24-31.76\%) (Table 2).

Table 2. Prevalence of bovine brucellosis in herds of dual-purpose cattle in nine municipalities of Caquetá state.

\begin{tabular}{lccc}
\hline \multicolumn{1}{c}{ Municipality } & $\begin{array}{c}\text { Number of herds } \\
\text { samples }\end{array}$ & $\begin{array}{c}\text { Number of herds } \\
\text { positives }\end{array}$ & Prevalence (\%) \\
\hline Albania & 10 & 1 & 10 \\
Cartagena del Chairá & 10 & 3 & 30 \\
El Doncello & 10 & 0 & 0 \\
El Paujil & 10 & 2 & 20 \\
La Montañita & 10 & 0 & 0 \\
Milán & 10 & 3 & 20 \\
Puerto Rico & 10 & 2 & 30 \\
San José del Fragua & 10 & 3 & 40 \\
San Vicente del Caguán & 20 & $\mathbf{2 2}$ & $\mathbf{2 2}$ \\
TOTAL & $\mathbf{1 0 0}$ & & \\
\hline
\end{tabular}

Different researchers have found minor's values of sero-prevalence of bovine brucellosis respect to this research, for example, in a study conducted in Montería, Córdoba, Colombia (González, Rios, \& Mattar, 2007), found that in 384 bovine females with infertility problems, the seropositive for brucellosis were $3.1 \%$. Likewise, found in 206 blood serum analyzed in the municipalities of Roscio and Ortiz a sero-prevalence of $2.9 \%$ (Tamasaukas, Purroy, Rodríguez, Ruiz, Roa, \& Labrador, 2002). In the same way, reported a sero-prevalence of 0,639 in livestock from Machiques de Perijá municipality in Venezuela, being the lowest for Latinamerica (Sánchez-Villalobos et al., 2009). In the municipality of La Plata, Huila, Colombia, found a sero-prevalence in livestock of $2.11 \%$ (Tejada \& Ayala, 2008). In the same way, found an overall sero-prevalence of $1.90 \%$ in the Huila state, neighbor to the Caquetá state, nevertheless, the same authors report at municipal level a maximum sero-prevalence of $4.52 \%$, value less than those found in municipalities in this research (Dussan-Embus, Castañeda-Repizo, \& DuránBautista, 2012).

Nevertheless, a research performed in the municipality La Cañada de Urdaneta in Venezuela, found a sero-prevalence of bovine brucellosis of $9.1 \%$, which is greater than this research (D’Pool et al., 2004).

In bulls located in Florencia municipality from Caquetá state Pinzón-Rendón \& Ramírez-Vargas (2004), found a sero-prevalence of brucellosis of $0 \%$, being coincident with the prevalence of brucellosis in males of the nine municipalities with the exception of Albania and Puerto Rico, where one case was presented respectively.

In a research developed by Nuñez-Motta \& Ochoa-Valderrama (1983), in animals destined for slaughter in the COFEMA slaughterhouse in Caquetá, where animals arrived from all the municipalities of the state, 2207 animals were samples being 
Desarrollo del girasol (Helianthus annuus L.) con aplicación de codornaza bajo distintas láminas de riego

the $99.64 \%$ females older to 36 months, and found a prevalence of brucellosis of $1.81 \%$, however, the authors included the suspicious cases as positives and so estimated a prevalence in $2.99 \%$. Also, the same authors referred than according to ICA in the year 1980 the prevalence of bovine brucellosis in Caquetá state was of $0.33 \%$.

Subsequently, performed a study of the epidemiology of bovine brucellosis from samples processed by ICA between the years 1990 and 1999 in the Caquetá state, 18,542 blood serum samples were analyzed found that $9.54 \%$ were positives to brucellosis (Arenas-Rojas, 2000). For the San José del Fragua municipality the positive cases represented the $13 \%$, Albania of $4.7 \%$, Milán of $9.7 \%$, Cartagena del Chairá of $18 \%$, San Vicente del Caguán of $6.26 \%$, Puerto Rico of $8.38 \%$, El Paujil of $7.74 \%$, El Doncello $4.65 \%$ and La Montañita $1.78 \%$. This author said that the brucellosis disease shows an increase from 4\% of cases in the year 1990 to $12 \%$ in the cases of 1999 .

In the year 2001 Hoyos-Colorado \& Santos (2002), performed a study about the prevalence of bovine brucellosis in 484 females destined to slaughter in the Caquetá state, found a prevalence of $3.3 \%$. Later, in 302 animals from 88 herds of five municipalities from Caquetá state, found a sero-prevalence of $0.33 \%$, with prevalence only in the Puerto Rico municipality with the $1.31 \%$ (Espinoza-Nuñez \& Hoyos-Sepúlveda, 2004). In a study performed in 297 bovine females from Caquetá state, they found a sero-prevalence of brucellosis of $5.40 \%$ (MottaGiraldo, Clavijo-Hoyos, Waltero-García, \& Abeledo, 2014).

Research performed at farm level found a prevalence of bovine brucellosis greater than this study, for example, in the municipality of Machiques de Perijá, SánchezVillalobos et al. (2009), determinate a prevalence of $69.29 \%$, which fell through a program of control and eradication to $27.25 \%$. In the Huila state neighbor to Caquetá, Dussan-Embus, Castañeda-Repizo, \& Durán-Bautista (2012), found prevalence in herds of $28.8 \%$.

In other studies, the prevalence of bovine brucellosis has been lower, D'Pool et al. (2004), determinate a prevalence at farm level of $20.3 \%$, which is similar to the results of this research, likewise Tique, González, \& Mattar, (2009), in a study performed in the Cordoba state from Colombia, found a prevalence a level of farm of $12.7 \%$ (635/4,922 farms). In the same way, a study in Mocoa Putumayo Colombia Marín \& Moncayo, (2007), determinate a prevalence of brucellosis to farm level of $18.9 \%$ through the technique of indirect Elisa in milk. For the Caquetá state Poveda \& Carrillo (1981), found prevalence in herds of $11.7 \%$.

Then, the sero-prevalence of bovine brucellosis in Caquetá state has gone from $0.33 \%$ in the year 1980 to $12 \%$ in 1999, nevertheless, the sero-prevalence has decreased for the efforts of the official control Institutions as ICA, being the seroprevalence in livestock low with the $3.23 \%$ for the year 2016. However, is necessary more effort by eradicating this zoonotic disease. 
In this regard and taking into account the epidemiological implications of the brucellosis disease, it is necessary strengthen of a programme of control and eradication of bovine brucellosis in a coordinated and sustained manner (Seleem, Boyle, \& Sriranganathan, 2009), affects people in contact with animals and derived products such milk, being that the animal reservoirs control allows a reduction of the incidence of the disease in humans.

\section{ConcLusions}

Bovine brucellosis in the Caquetá state has a low sero-prevalence being of $3.23 \%$ in cows older to 36 months and moderate prevalence at farm level with $22 \%$ of the herds samples, which indicates that despite a low incidence of the disease in animal and moderate in herd, it is necessary a greater performance of official control entities at farm level to reduce and eradicate the disease for guarantee the safety of milk and therefore the health of consumers.

\section{ACKNOWLEDGMENTS}

The authors are grateful to the governorship of Caquetá as executor of the resources of the project BPIN 2013000100164 funded by the FCTel of the SGR and the team of Misión Verde Amazonia Corporation by enabling the development of this research.

\section{REFERENCES}

Aguirre, A. V., Alvarado, G. M., Ibave, G. J., Leal, H. M., Díaz, A. E., Nevárez, M. G., Solis, M. F., Arévalo, G. S., \& Rivera, C. B. (2008). Duplex polymerase chain reaction as a rapid, effective diagnostic test for bovine brucellosis using blood samples. Técnica Pecuaria en México, 46(2), 147-158.

Akbarmehr, J., \& Ghiyamirad, M. (2011). Serological survey of brucellosis in livestock animals in Sarab City (East Azarbayjan province), Iran. African Journal of Microbiology Research, 5(10), 1220-1223. https://doi.org/10.5897/ajmr11.180

Alton, G., \& Forsyth, J. (2003). Brucellosis. Medical Microbiology, 28, 512-525.

Arenas-Rojas, W. (2000). Análisis estadístico de brucelosis en bovinos, sobre el número de muestras reportadas al centro de diagnóstico ICA en los años 1990 - 1998 en el departamento del Caquetá. Florencia: Universidad de la Amazonia.

Astaiza, J. (2012). Estudio de costo-efectividad del Programa de vacunación contra Brucella abortus en bovinos en el departamento de Nariño. Revista Colombiana de Ciencias Químico-Farmacéuticas, 41(2), 167-186.

Ayinmode, A., Akinseye, V., Schares, G., \& Cadmus, S. (2017). Serological survey of toxoplasmosis, neosporosis and brucellosis among cattle herds in Oyo State, south-western Nigeria. African Journal of Infectious Diseases, 11(2), 95-101. https://doi.org/10.21010/ajid.v11i2.13

Beltrán-Barreiro, Y., \& Torrijos, R. (2013). Linea base de la industria láctea del Caquetá. Florencia: Comité Departamental de Ganaderos del Caquetá y Cámara de Comercio de Florencia para el Caquetá.

Caquetá (2016). Consolidado Pecuario EVA 2016. Florencia: Gobernación del Caquetá - Secretaría de Agricultura Departamental.

Carvalho-Neta, A., Mol, J., Xavier, M., Paixão, T., Lage, A., \& Santos, R. (2010). Pathogenesis of bovine brucellosis. The Veterinary Journal, 184(2), 146-155. https://doi.org/10.1016/j.tvjl.2009.04.010

Castro, H., González, S., \& Prat, M. (2005). Brucellosis: a pratical review. Acta Bioquímica Clínica Latinoamericana, 39(2), 203-2016.

Corpoica (1998). Aspectos de los suelos del departamento del Caquetá con relación al uso y manejo. Florencia: Corporación Colombiana de Investigación Agropecuaria.

D’Pool, G., Rivera, P., Torres, T., Pérez, M., García, A., Castejón, O., y otros. (2004). Prevalence of Bovine Brecellosis using the competitive Elisa test in La Cañada de Urdaneta municipality, Zulia State, Venezuela. Revista científica FCV-LUZ, 14(2), 168-176. 
Desarrollo del girasol (Helianthus annuus L.) con aplicación de codornaza bajo distintas láminas de riego

Di Rienzo, J., Casanoves, F., Balzarini, M., González, L., Tablada, M., \& Robledo, C. (2017). Infostat versión 2017. Cordoba: Universidad Nacional de Córdoba.

Dussan-Embus, R., Castañeda-Repizo, M., \& Durán-Bautista, E. (2012). Seroprevalencia de Brucella abortus en bovinos del departamento del Huila - Colombia. Momentos de Ciencia, 9(2), 133-141.

Espinoza-Nuñez, A., \& Hoyos, J. (2004). Prevalencia de las enfermedades reproductivas (leptospira, brucelosis, IBR y DVB) en algunas fincas de los municipios de la Montañita, Cartagena del Chairá, Paujil, Doncello, San Vicente del Caguán y Puerto Rico en el Caquetá. Florencia: Universidad de la Amazonia.

Fedegan (2013). Programa de prevención, control y erradicación de la brucelosis bovina. Recuperado de: http://www.fedegan.org.co/programas/programa-de-prevencion-control-y-erradicacion-de-la-brucelosisbovina

García, J., Cipagauta, M., Gómez, J., \& Gutierrez, A. (2002). Descripción, espacialización y dinámica de los sistemas de producción agropecuaria en el área intervenida del departamento de Caquetá. Florencia, Caquetá: Corporación Colombiana de Investigación Agropecuaria.

Gobernación de Caquetá (2012). Plan desarrollo 2012-2015. Caquetá, Colombia: Gobernación de Caquetá.

González, M., Rios, R., \& Mattar, S. (2007). Prevalece of bacteria associated with infectious infertility in bovines of Monteria, Colombia. Revista MVZ Córdoba, 12(2), 1028-1035. https://doi.org/10.21897/rmvz.423

Holdridge, L. (1978). Life zone ecology (Quinta reimpresión ed.). San José, Costa Rica: Instituto Interamericano de Cooperación para la Agricultura.

Hoyos-Colorado, A., \& Santos, M. (2002). Prevalencia de brucelosis en hembras bovinas mayores de dos años sacrificadas en el matadero de COFEMA. Florencia: Universidad de la Amazonia.

Maadi, H., Moharamnejad, M., \& Haghi, M. (2011). Prevalence of Brucellosis in cattle in Urmia, Irán. Pakistan Veterinay Journal, 31(1), 81-82.

Marín, S., \& Moncayo, C. (2007). Determinación de la prevalencia de brucelosis bovina en el municipio de Mocoa, departamento del Putumayo. Florencia: Universidad de la Amazonia.

Matope, G., Bhebhe, E., Muma, J., Oloya, J., Madekurozwa, R., \& Lund, A. (2011). Seroprevalence of brucellosis and its associated risk factor in cattle from smallholder dairy farms in Zimbawe. Tropical Animal Health and Production, 43(5), 975-982. https://doi.org/10.1007/s11250-011-9794-4

Motta-Giraldo, J., Clavijo-Hoyos, J., Waltero-García, I., \& Abeledo, M. (2014). Seroprevalence of Brucella abortus, Leptospira sp. and Neospora caninum in cattle, buffaloes and mixed farms, in the Departament of Caquetá, Colombia. Revista de Salud Animal, 36(2), 80-89.

Nuñez-Motta, E., \& Ochoa-Valderrama, A. (1983). Análisis estadístico de edad, peso, sexo, estado reproductivo y prevalencia de brucelosis en bovinos sacrificados en el Matadero de Florencia. Florencia: Universidad de la Amazonia.

Pathak, A., Dubal, Z., Karunakaran, M., Doijad, S., Raorane, A., \& Dhuri, R. (2016). Apparent seroprevalence, isolation and identification of risk factors for brucellosis among dairy cattle in Goa, India. Comparative Immunology, Microbiology and Infectious Diseases, 47, 1-6. https://doi.org/10.1016/..cimid.2016.05.004

Pinzón-Rendón, C., \& Ramírez-Vargas, J. (2004). Presencia de cuatro enfermedades reproductivas de transmisión sexual (Brucelosis, Leptospira, IBR y DVB) en machos reproductores bovinos en los hatos doble propósito de la vereda Balcanes. Florencia: Universidad de la Amazonia.

Poveda, A., \& Carrillo, U. (1981). Estudio de brucelosis en hatos lecheros del Caquetá. Florencia: Instituto Colombiano Agropecuario.

Reyes, J., Sánchez, M., Lotero, M., Restrepo, M., \& Palacio, L. (2010). Seroprevalence and incidence of Brucella sp among workers of the brucelosis control program in department of Antioquia, Colombia. Revista Colombiana de Ciencias Pecuarias, 23(1), 35-46.

Sánchez-Villalobos, A., Villarroel-Neri, R., Oviedo-Bustos, A., Sandrea, G., Boscán-Ocando, J., \& Pinto-Patiño, R. (2009). Epidemiologic surveillance system of Brucella abortus in dual purpose farms of Machiques de Perijá county, Venezuela: Prevalence, risk, factors and control program. Revista Científica FCV-LUZ, 19(4), 325-333.

Seleem, M., Boyle, S., \& Sriranganathan, N. (2009). Brucelosis: a re-emerging zoonosis. Veterinary Microbiology, 140(3-4), 392-398. https://doi.org/10.1016/j.vetmic.2009.06.021

Tamasaukas, R., Purroy, R., Rodríguez, H., Ruiz, I., Roa, N., \& Labrador, C. (2002). Seroprevalence of bovine Trypanosomosis and Brucellosis in integrated farms with maize, of high lands of Roscio and Ortiz counties, Guarico State, Venezuela. Revista Científica FCV-LUZ, 12(2), 589-594.

Tejada, C., \& Ayala, S. (2008). Prevalencia de brucelosis bovina en fincas de vinculados a la asociación de ganaderos de la Plata - Huila (ASOGANPLAT). Florencia: Universidad de la Amazonia.

Tique, V., González, M., \& Mattar, S. (2009). Seroprevalence of Brucella abortus in cattle of the Cordoba department. Revista UDCAA Actualidad \& Divulgación Científica, 12(2), 51-59.

Yamamoto, W., Dewi, I., \& Ibrahim, M. (2007). Effects of silvopastoral areas on milk production at dualpurpose cattle farms ar the semi-humid old agricultural frontier in central Nicaragua. Agricultural Systems, 94, 368-375. https://doi.org/10.1016/i.agsy.2006.10.011

Ciencia y Agricultura (Cien. Agri.) Vol. 17 (1). L-ISSN 0122-8420. elSSN 2539-0899.

Enero-Abril 2020, pp. 19-30. Tunja (Boyacá) - Colombia. DOI:

https://doi.org/10.19053/01228420.v17.n1.2020.9917 